\title{
Guesthouses in the Maldives: Towards Community-Based Tourism
}

Musliha Ahmed

Faculty of Hospitality and Tourism Studies, Male, Maldives

\begin{abstract}
The Guesthouses sector in the Maldives is a rapidly growing sector which gives visitors a cheaper alternative for mid to low market segments. The permission to operate Guesthouses in the inhabited islands of Maldives was granted in 2009. These accommodations mostly provided only lodging facilities for the visitors although some are connected with FandB outlets. The sector accounts for $16 \%$ of the of the total bed capacity in the Maldives. This research proves that there are implications in proceeding with the Guesthouse businesses in the local islands. One negative impact is socio-cultural. Maldivians have been used to living in small island communities undisturbed from foreigners and for this reason, many locals in the island communities think that hosting foreigners year-round destroys their unique way of life, and hence they do not encourage the rapid progress of Guesthouse businesses. For this reason, the integration of local communities with Guesthouse to urism is not an easy endeavor. Even though this form of tourism is supported by the Maldivian government, it was found that many locals still have reservations on integrating with the tourists due to the socio-cultural differences. The findings of this research led the author to conclude that Community Based Tourism can be a solution if effectively implemented.
\end{abstract}

Keywords: The Maldives, Community integration, Culture, Community based tourism, Guesthouses

\section{Introduction}

Tourism in the Maldives has been contributing to more than $22 \%$ of the national GDP for the last five years. In the year 2016 tourism contributed to $22.7 \%$ while the closest sector was transport and communication contributing to $13.3 \%$. The accommodation facilities present in the Maldives include resorts, safari vessels, and guesthouses. Although secluded tourist resorts have been in operation since the early 1970s, guesthouses were permitted to operate in inhabited islands only in 2009. While the Maldives consist of 1990 islands out of which 202 are inhabited, a total of 393 guesthouses were found in 77 inhabited islands at the end of 2016. The bed capacity saw an increase of $23 \%$ from 4,649 in 2015 to 6,044 by the end of 2016 (Tourism Year Book 2017).

Community involvement is no doubt important in this sector. In order for Community Based Tourism (CBT) to take place, support from all stakeholders, especially the locals are needed. The main research objectives of this paper are:

- to analyze the current integration of guesthouses in local communities.

- to explain how CBT could be a solution to resolve the existing socio-cultural tensions that exist in operating guesthouses in the Maldives.

Many issues were identified by different stakeholders, which, if not addressed by the authorities will hinder the development of these islands as well as the satisfaction, trust, and support of the communities towards the authorities and the visitors. Furthermore, if CBT is to be 


\section{Musliha Ahmed \\ Guesthouses in the Maldives: Towards Community-Based Tourism}

established in the Maldives or any other Small Island Developing State (SIDS), the dire need to build a high level of community integration and support as well as stakeholder involvement and collaboration in order to a chieve success. If the local island communities' initiate to urism, rather than the government or the private sector, the socio-cultural barriers that exist would be automatically eliminated to a great extent as they would be designing their own CommunityBased Tourism.

\subsection{Problem Statement}

The rapid growth of the guesthouse businesses in the island communities in the Maldives cases several problems as the initial plans where not done involving the communities living in the same islands. This causes several problems, especially socio-cultural.

\subsection{Aim of the Study}

It is important to make the stakeholders, especially the central government of the Maldives, aware of the importance of trying to solve the existing problems by initiating Community Based Tourism in the islands before more Guesthouses come up in several other islands of the Maldives where the concept is not yet introduced. Moreover, the islands where the concept is being practiced also need a turn-around towards Community-Based Tourism.

\section{Literature Review}

The Maldives remained largely unknown to tourists until the early 1970s. There is a total of 1196 islands of which 202 islands are home to its 300,000 inhabitants while visitor arrivals have exceeded above one million in the past five years. Guesthouses are found in the previously mentioned 202 islands. Under the Tourism Act Law No. 2/99, all facilities providing accommodation to tourists visiting the Maldives are required to register at Ministry of Tourism under the respective category. Accommodation facilities, along with its bed capacity has been increasing at an average rate of $7 \%$ over the last five years. At the end of 2016 , the total number of registered accommodation facilities in the Maldives was 679 with a total bed capacity of 37,482 , which was, an increase of $10 \%$ compared with the 34,085 beds in 2015 . Tourist arrival patterns in the Maldives over the last five years have been strong. Arrivals remained consistent and reached targets, attaining $+10 \%$ as five-year annual average growth rate from 2012 to 2016. Annual arrival numbers remain above one million (Tourism Yearbook, 2017).

Tourism dominates the national GDP, and therefore the Maldives is very dependent on the sector. Development of tourism is considered to be characterized by a condition of dependency (Sharpley, 2001; 2003). Dependency is defined as "a conditioning situation in which the economies of one group of countries are conditioned by the development and expansion of others" (Dos Santos, 1970, p. 231). Scholars argue that in small islands, tourism development and the characteristics of the tourism industry have been found to reflect the center-periphery dependency model of development (Hoivik and Heiberg, 1980; Opperman, 1993) where the majority of tourists come from developed countries (Khan, 1997). As a result of the political economy of international tourism (Bianchi, 2002), there are parallels between tourism development and dependency theory, particularly in island economies (Sharpley, 2003). Tourism can also have both positive and negative outcomes for residents in communities where sharing and preserving their culture could be seen as conflicting goals (Besculides, 2002).

After the term emerged in the mid-1990s, Community Based Tourism (CBT) is found to be a generally small scale concept which involves interactions between visitor and host community, which is particularly suited to small islands. CBT commonly understood to be managed and owned by the community, is a form of 'local' tourism, favoring local service providers and suppliers. CBT focuses on interpreting and communicating the local culture and environment and has been pursued and supported by communities, local government agencies and 


\author{
Musliha Ahmed \\ Guesthouses in the Maldives: Towards Community-Based Tourism
}

non-government organizations (NGOs). There is a range of actual legal forms of the ownership and management in which communities participate (APEC, 2010). Weaver (2010) observed that CBT was referred to in the early 1980 s as the 'sine qua non' of alternative tourism. Hopes were especially high of combatting mass tourism in the developing world and aiding rural communities in the global south through grassroots development, resident participation, empowerment, and capacity building (Scheyvens, 2002). According to Dangi and Jamal (2016), he advocated a system's perspective of community tourism where "community" very broadly refers to a group of people living in a defined space, and visitors interact with local people and landscape for a tourism experience (cited in Murphy, 1995).

\title{
3. Research Methodology
}

Over the period of two years, four sets of interviews were conducted on the islands of Thulusdhoo and Maafushi. Thulushdoo was chosen as it was found to be a potential destination for budget travelers with many new Guesthouses being built. Maafushi was chosen to compare with Thulusdhoo as it is the best performing island in guesthouse tourism and the first island to introduce the concept.

From both islands, interviews were conducted twice within a two-year interval with:

- the local government councils

- locals

- Guesthouse managers or owners

- visitors

The transcripts (apart from the ones taken from the tourists) were translated to English, and the texts were coded and analyzed using the qualitative analysis software QDA Miner, which is a content analysis plus text mining software. It helped the author to organize the data and code them to find out the key problems that existed in the communities.

\section{Data Analysis and Interpretation}

As indicated earlier, trees were generated after coding and analyzing the data using the qualitative analysis software QDA miner and the major issues identified are mentioned below:

Many issues were identified during the interviews in Thulusdhoo and Maafushi as evident below.

\subsection{Dress Code of Visitors}

One of the common issues highlighted by the locals was their concern about the tourists' dress code. While there was a beach area officially allocated for tourists in Maafushi and one was being prepared at Thulusdhoo at the time of the interviews, the locals were disturbed when the guests dressed in bikinis walked around the roads. Although it might be common for visitors, locals, especially the eldergeneration aren't willing to adapt to the idea. Some see this as an offense to their way of living (Personal interview with locals 2, 5 and 6, Thulusdhoo. January 2016).

\subsection{Hiring of Foreign Labour}

The issue of foreign labor was more significant in Thulusdhoo than Maafushi. According to a local from Thulusdhoo, the Guesthouse managers are not concerned with the economic contribution to the island. These managers employ foreign labor, and as the foreigners send money abroad, the islands are not getting much income from labor (Personal interview with local 3 from Thulusdhoo, January 2016). 


\section{Musliha Ahmed \\ Guesthouses in the Maldives: Towards Community-Based Tourism}

\subsection{Youth Being Deviated from the Religion}

Interviewees in both the communities of Maafushi and Thulusdhoo expressed concern that the youth are being deviated from Islam with the introduction of guesthouse businesses (Personal communication, local 4 Maafushi, December 2016). An owner/manager in one of the guesthouses in Maafushi also raised concern over the issue saying that he foresees a significant level of influence from the guests staying on the island to hinder the existing beliefs of the locals (Personal communication, guesthouse manager (GHM) 2, Maafushi, December 2015).

\subsection{Locals not Willing to Work}

One GHM in Thulusdhoo pointed out that it is difficult to retain locals in the jobs related to hospitality as there is a lack of discipline among Maldivian youths who do not stay in one job for long and keep moving from one job to another for better pay (Personal Communication, GHM 3, Thulusdhoo, January 2016). A trend has been established in the Maldives to hire foreigners from neighboring countries such as India, Sri Lanka, Nepal and more recently from Bangladesh for such jobs as the labor cost is much cheaper and as they are required to work until the end of their contracts.

\subsection{Lack of Cooperation among Guesthouse Management (GHM) of the Same Island} Another problem highlighted in the interviews at Thulusdhoo was the fact that the cooperation amongst the GHM was weak and hence, they face problems in managing waste, keeping the island clean and other important issues. Thus, the importance of cooperation among different stakeholders was highlighted by locals as well as GHMs or owners who were interviewed (Personal Communications, Locals 3, 5,7 and GHMs 2, 5, Thulusdhoo, January 2016).

\subsection{Limited Support from the Local Government Council (LGC) and the Central Government}

This was the most significant issue raised by locals and some GHMs. They pointed out that for anything to be accomplished, they need full support from the LGCs and the central government. Improving the utility functions and the infrastructure of the islands was the ma in area in which both islands needed support (Personal Communication, locals (1-10) from both islands; GHMs 2, 4 and 7 of Thulusdhoo and GHMs 1, 3 and 4 of Maafushi, January 2018).

\subsection{Distribution of Taxes Raised from Tourism}

According to the Maldives Inland Revenue Authority (MIRA), the green tax is a tax payable by foreign tourists at the rate of $\$ 6$ per day of stay in resorts, hotels and safari vessels and $\$ 3$ per day of stay in guesthouses (www.mira.gov.mv). MIRA then forwards the collected taxes to the Ministry of Finance which allocates the budget to the country's different development projects. The councils of both Maafushi and Thulushdoo expressed their concern about the amounts that are re-allocated back to them from the central government. There is a disconnect between what the guesthouses generate in tourism taxes and what they are allowed to keep.

Most locals also believe that the islands do not receive any proportion of the green tax that their islands earn. The locals said that even if a percentage of the green tax is allocated to the islands through which they are earned, the islands could work on environmental projects to improve the island (Personal communication, locals 2, 5 and 10, December 2015 and January 2016).

\subsection{Tourists' Comments}

Even though most of the comments given by the tourists who were interviewed at both the islands were positive, according to Local 2 in Maafushi, the guest mentioned that although the green tax is being collected, they do not see any positive changes to the island. Tourist 3 was not happy as to how the guesthouse concept in the Maldives is evolving to that of the hotel concept (Personal communication, Tourist 3, December 2015). As observed in both islands, the cultural activities in the islands were not enough to support the visitors and that the islanders do not engage in producing authentic local products. 


\section{Conclusion and Recommendations}

\subsection{Proposed Theory}

Reid, Fuller, Haywood and Bryden, (1993) created a model of the entrepreneurial approach to tourism development, which focuses attention on involving stakeholders in the process, not just as a tokenistic exercise but in a real and constructive manner. This, in fact, is found to be lacking in the Maldivian Guesthouse concept.

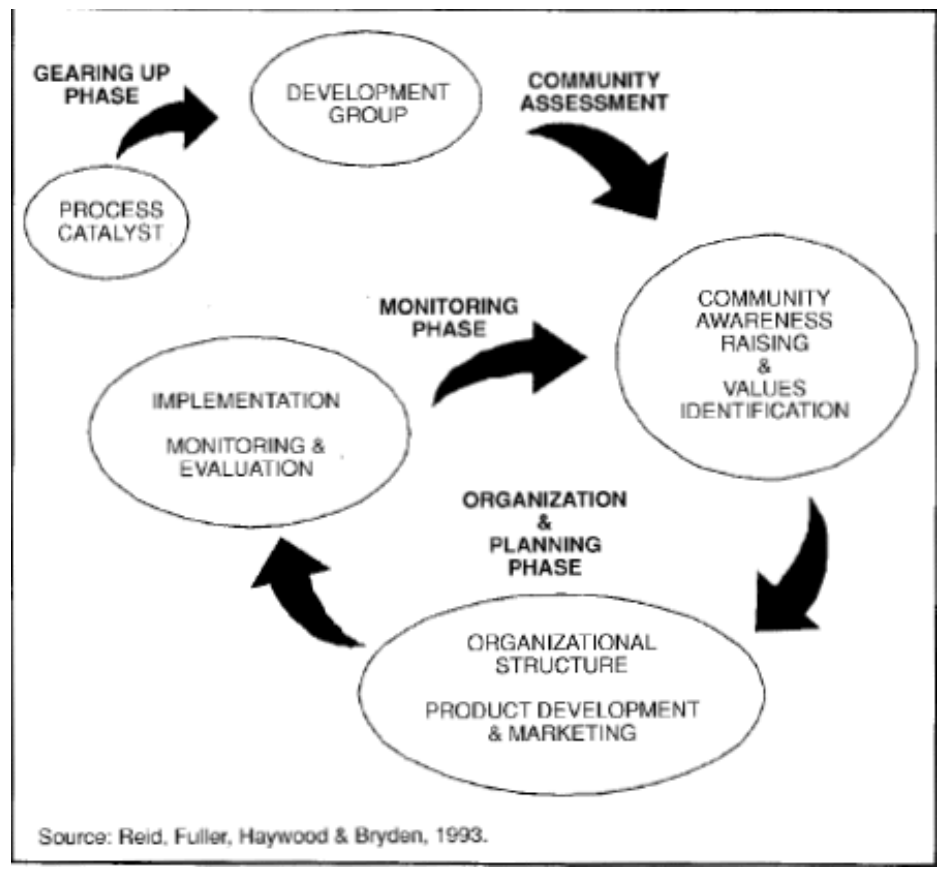

Figure 1

According to the model (Community Awareness Raising and Values Identification), community integration is vital for Maldives' tourism development in the local islands. Community Based Tourism is often enforced upon communities by concerned government authorities rather than being initiated by the locals. Total integration is essential and that the initiative should come from the locals rather than the government. Therefore, a change in the government mindset is essential for the locals to proceed with Community Based Tourism. Furthermore, the research also found the importance of stakeholder involvement and collaboration as essential factors.

The central government's role could be achieved by the involvement of the Maldivian Ministry of Tourism. The local government also needs to build a closer relationship with the communities. The cultural barriers that exist may be eliminated with the building of trust among the communities. In fact, it could be interesting for tourists to see the high level of community involvement and respect the locals have for their culture. Conducting community awareness programs on the knowledge and importance of CBT for the development of the islands should be a priority in all the islands where tourism takes place.

\subsection{Conclusion}

The two main questions of the study have been answered. This study, therefore, concludes that there are significant issues which need to be resolved to better improve the guesthouse sector in the inhabited islands of the Maldives, and can only be achieved by properly implementing Community Based Tourism. 


\author{
Musliha Ahmed \\ Guesthouses in the Maldives: Towards Community-Based Tourism
}

\title{
Acknowledgments
}

I am grateful to my PhD supervisor Professor Cecile Clergeu from the University of Nantes, France for the guidance provided throughout the research and Dr.Kimberly Monk from Southem New Hampshire University, the USA for proof-reading this article. Furthermore, the people, councilors, Guesthouse managers or owners and the tourists that I met and interviewed during my various stays in both islands should be acknowledged in this list. My workplace, the Maldives National University should be thanked for facilitating the research, and my family, especially my loving husband and children, cannot be thanked enough for their support and patience.

\section{References}

- Ajzen, I., and Fishbein, M. (1980). Understanding attitudes and predicting social behaviour, Prentice-Hall.

- Asia Pacific Economic Corporation (APEC) (2010). Effective Community Based Tourism, Sustainable Tourism Cooperative Research Centre, Australia, (pp2).

- Besculides A. Peter, M.E.L. Cormick J, Mc. (2002). Resident's perceptions of the cultural benefits of tourism, Annals of Tourism Research, Volume 29, Issue 29(2), 303-319.

- Bianchi, R. (2002). Toward a new political economy of global tourism. In R. Sharpley and D. Telfer (Eds.), Tourism and development: Concepts and issues (pp. 265-299). Clevedon: Channel View

- Cook, K.S., Cheshire, C., Rice, E.R.W., Nakagawa, S. (2013). Social Exchange Theory. In: DeLamater J., Ward A. (eds) Handbook of Social Psychology. Handbooks of Sociology and Social Research. Springer, Dordrecht. Crossref

- Dos Santos, T. (1970). The structure of dependency. American Economic Review, 60(2), 231-236.

- Hoivik, T. and Heiberg, T. (1980). Centre-periphery tourism and self-reliance. International Social Science Journal, 32(1), 69-98.

- Khan, M. M. (1997). Tourism development and dependency theory: Mass tourism vs. ecotourism. Annals of Tourism Research, 24(4), 988-991. Crossref

- Murdvee, M. (2009), "Social Exchange", Retrieved February 23, 2018, Available from from https://www.ttu.ee/public/m/mart-murdvee/EconPsy/5/6._EconPsy__Social_exchange.pdf

- Mayer, R.C., Davis, J.H. and Schoorman, F.D. (1995). An integrative model of organizational trust, Academy of Management Review, Vol. 20, pp. 715. Crossref

- Ministry of Tourism. (2017) Tourism Yearbook 2017, Retrieved from http://www .tourism.gov.mv/statistics/annual-publications/

- MIRA-"About us" page, Retrieved February 9, 2018, Maldives Inland Revenue Authority website, https://www.mira.gov.mv/AboutUs.aspx

- Okazaki, E. (2008). A Community-Based Tourism Model: It's Conception and Use, Journal of Sustainable Tourism 16(5):511-529). Crossref

- Opperman, M. (1993). Tourism space in developing countries. Annals of Tourism Research, 20(4), 535-556. Crossref

- Qualitative Data Analysis Software, Montreal, Retrieved January 27, 2018, Provalis Research website https://provalisresearch.com/products/qualitative-data-analysissoftware/

- Rousseau, D. M., Sitkin, S. B., Burt, R. S. and Camerer, C. (1998). 'Not So Different After All: A Cross-discipline View of Trust', Academy of Management Review 23(3): 393404. Crossref

- Sharpley, R. (2009). Tourism, Environment and Development Series Series, School of Sport, Tourism and The Outdoors, University of Central Lancashire, UK

- Sharpley, R. (2001). Tourism in Cyprus: Challenges and opportunities. Tourism Geographies, 3(1), 64-86. Crossref 
Musliha Ahmed

Guesthouses in the Maldives: Towards Community-Based Tourism

- Sharpley, R. (2003). Tourism, modernization and development on the island of Cyprus: Challenges and policy responses. Journal of Sustainable Tourism, 11(2and3), 246-265. Crossref

- T.B. Dangi and T.Jamal, An Integrated Approach to "Sustainable Community-Based Tourism", Department of Recreation, Park and Tourism Sciences, Texas AandM University, College Station, TX 77843, USA. Retrieved from http://ww.mdpi.com 